\title{
PENGARUH MURABAHAH DAN STRUKTUR MODAL SENDIRI TERHADAP IMBAL HASIL STUDI PADA BPR SYARIAH DI PULAU JAWA
}

\author{
Rinto Noviantoro \\ Umar Purwoko \\ Fakultas Ekonomi Universitas Dehasen Bengkulu \\ Universitas Trisakti \\ rintonoviantoro@yahoo.co.id
}

\begin{abstract}
ABSTRAK
Rinto Noviantoro, Umar Purwoko; Penelitian ini bertujuan untuk mengetahui pengaruh pertumbuhan dan penyertaan modal murabahah tentang pengembalian berupa pengembalian aktiva pada Bank Rakyar Syariah (SRB) di Pulau Jawa pada periode kuartalan yaitu periode laporan Neraca Maret 2011 s / D pada bulan Desember 2012 diterbitkan. Uji hipotesis menggunakan uji linier berganda yang menguji pengaruh antara murabahah dan struktur modal ekuitas pertumbuhan sebagai variabel bebas terhadap variabel yield sebagai dipenden. Metode pengumpulan data sekunder adalah dengan menggunakan analisis kuantitatif. Uji statistik menggunakan Asumsi Uji Klasik.

Hasil penelitian ini menunjukkan bahwa struktur murabahah dan modal ekuitas berpengaruh secara signifikan terhadap yield, dimana berbeda hasil bahwa pertumbuhan murabahah berpengaruh negatif signifikan terhadap BPR Syariah maka struktur modal itu sendiri berpengaruh positif signifikan terhadap yield pada BPR Syariah.
\end{abstract}

\section{ABSTRACT}

Rinto Noviantoro, Umar Purwoko; This research was aimed to determine the effect of growth and equity financing murabahah about returns in the form of return on assets in the Bank's Credit Rakyar Sharia (SRB) in the island of Java in the period quartalan ie Balance Sheet reporting period March $2011 \mathrm{~s} / \mathrm{d}$ in December 2012 were published. The hypothesis testing using multiple linear test that examines the effect between murabaha and growth equity capital structure as an independent variable to variable yields as dipenden. Secondary Data collection method is by using quantitative analysis. Test statistics using Classical Test assumptions.

The results of this study indicate that the murabahah and equity capital structure significantly influence yield, whereby the different results that the growth murabaha significant negative effect on BPR Syariah then capital structure itself significant positive effect on the yield on Syariah BPR

Key Words: Murabahah , Own Capital Structure, and yields

\section{PENDAHULUAN}

Industri perbankan syariah yang terjadi di Indonesia tergolong yang tertinggi di dunia hal ini disampaikan oleh Ketua Tim Peneliti Direktorat Perbankan Syariah Bank Indonesia (BI) Dhani Gunawan dalam Seminar Syariah Banking Outlook 2012 di Kampus UMI Makassar sabtu (11/6/2011), menyatakan bahwa "posisi Indonesia di pasar global mengalami industri hingga 46,5\% dalam lima tahun terakhir, lebih tinggi dari industri keuangan syariah yang berkisar 15-20\%.

Tabel 1. Perkembangan Industri Syariah

\begin{tabular}{|l|c|c|c|c|c|c|c|c|}
\hline \multicolumn{1}{|c|}{ Indikasi } & 2005 & 2006 & 2007 & 2008 & 2009 & 2010 & 2011 & 2012 \\
\hline BUS & 3 & 3 & 3 & 5 & 6 & 11 & 11 & 11 \\
\hline KP/UUS & 19 & 20 & 25 & 27 & 26 & 23 & 23 & 24 \\
\hline BPRS & 95 & 105 & 114 & 131 & 139 & 150 & 153 & 155 \\
\hline
\end{tabular}

Sumber : BI, Statistik Perbankan Syariah, Januari 2012.

Perkembangan akad jual beli murabahah untuk saat ini masuk dalam kategori populer yaitu sejak diterbitkannya Pedoman Standar Akuntansi Keuangan yang lebih spesifik mengenai murabahah 
yaitu PSAKno. 102 yang berlaku efektif awal januari 2008.

Tabel 2. Komposisi Pembiayaan Yang Diberikan Bank Syariah Juni 2012 (dalam milyar rupiah)

\begin{tabular}{|l|l|l|l|l|l|l|l|l|}
\hline \multicolumn{1}{|c|}{ Akad } & \multicolumn{1}{c|}{$\mathbf{2 0 0 5}$} & \multicolumn{1}{c|}{$\mathbf{2 0 0 6}$} & $\mathbf{2 0 0 7}$ & $\mathbf{2 0 0 8}$ & \multicolumn{1}{c|}{$\mathbf{2 0 0 9}$} & $\mathbf{2 0 1 0}$ & \multicolumn{1}{c|}{$\mathbf{2 0 1 1}$} & \multicolumn{1}{c|}{$\mathbf{2 0 1 2}$} \\
\hline Mudharabah & 3,124 & 4,062 & 5,578 & 6,205 & 6,597 & 8,631 & 10,229 & 9,549 \\
\hline Musyarakah & 1,898 & 2,335 & 4,406 & 7,411 & 10,412 & 14,624 & 18,960 & 16,295 \\
\hline Murabahah & 9,487 & 12,624 & 16,553 & 22,486 & 26,321 & 37,508 & 56,365 & 46,161 \\
\hline Salam & 0 & 0 & 0 & 0 & 0 & 0 & 0 & 0 \\
\hline Istishna & 282 & 337 & 351 & 369 & 423 & 347 & 326 & 322 \\
\hline Ijaroh & 316 & 836 & 516 & 765 & 1,305 & 2,341 & 3,839 & 2,927 \\
\hline Qord & 125 & 250 & 540 & 959 & 1,829 & 4,731 & 12,937 & 7,362 \\
\hline \multicolumn{1}{|c|}{ Total } & 15,232 & 20,445 & 27,944 & 38,195 & 46,886 & 68,181 & 102,655 & 82,616 \\
\hline
\end{tabular}

Sumber : Statistik Perbankan Syariah Juni 2012

Sementara fenomena yang terjadi pada saat ini dalam kita lihat pada tabel 1.2 yaitu komposisi pembiayaan yang menjadi produk murabahah adalah menduduki prosentase tertinggi diantara produk pembiayaan yang lainnya dan ini juga dibuktikan dengan semakin tingginya peningkatan pembiayaan murabahah dari tahun ke tahun.

Peraturan Bank Indonesia no 11/23/PBM/2009, tentang pembiayaan Bank Rakyat Syariah, pasal 5 tentang batasan paling kecil modal disetor paling kurang

Kinerja suatu bank. Ukuran profitabilitas yang digunakan adalah Return on Equity (ROE) untuk perusahaan pada umumnya dan return on asset (ROA) pada

Dari uraian di atas maka penulis tertarik untuk menyusun penulisan ilmiah dengan judul, "Pengaruh Tingkat Murabahah dan Struktur Modal Sendiri Terhadap Imbal Hasil, Studi Pada BPR Syariah di Pulau Jawa Periode Quaralan Maret 2011 s/d Desember 2012".

\section{TINJAUAN PUSTAKA}

\section{Pengertian Bank Syariah}

Pengertian bank menurut UU No. 7 Tahun 1992 tentang Perbankan sebagaimana telah diubah dengan UU No. 10 Tahun 1998 yang menjelaskan apakah fungsi bank umum dan bank perkreditan rakyat, kemudian dalam perkembangannya pemerintah untuk saat sekarang ini telah mengesahkan Undang Undang No 21 tahun 2008, Tentang Perbankan Syariah dalam ketentuan umum menyatakan bahwa :

"Perbankan Syariah adalah segala sesuatu yang menyangkut tentang Bank Syariah dan Unit Usaha Syariah, mencakup kelembagaan, kegiatan usaha, serta cara dan proses dalam melaksanakan kegiatan usahanya dalam hal ini Bank adalah badan usaha yang menghimpun dana dari masyarakat dalam bentuk Simpanan dan menyalurkannya kepada masyarakat dalam bentuk kredit dan/atau bentuk lainnya dalam rangka meningkatkan taraf hidup rakyat

Implementasai transaksi yang sesuai dengan paradigma dan asas transaksi syariah harus memenuhi karakteristik dan persyaratan antara lain: (1)Transaksi hanya dilakukan berdasar prinsip saling faham dan saling rida, (2)Prinsip kebebasan bertransaksi diakui sepanjang objeknya halal dan baik(3)Uang hanya berfungsi sebagai alat tukar dan satuan pengukur nilai, bukan sebagai komoditas.(4)Tidak mengandung unsur riba.(5)Tidak mengandung unsur kezaliman.(6)Tidak mengandung unsur maysir.(7)Tidak mengandung unsur gharar.(8)Tidak mengandung unsur haram.(9)Tidak menganut prinsip nilai waktu dari uang (time value of money) (no gain without accompanying risk) (10) tidak diperkenankan menggunakan standar ganda harga untuk satu akad serta tidak menggunakan dua transaksi barsamaan yang berkaitan (ta'alluq) dalam satu akad.(11) Tidak ada distorsi harga melalui rekayasa permintaan (najasy), maupun melalui rekayasa penawaran (ihtikar).(12)Tidak mengandung unsur kolusi dengan suap-menyuap (risywah).

\section{Pembiayaan Murabahah}

Sesuai dengan PSAK 102, tahun 2008 revisi tahun 2013 tentang Akuntansi Murabahah, pada 
paragraf 5 menyatakan bahwa:

Murabahah adalah akad jual beli barang dengan harga jual sebesar biaya perolehan ditambah keuntungan yang disepakati dan penjual harus mengungkapkan biaya perolehan barang tersebut kepada pembeli.

1. Karakteristik Murabahah,(Wiroso 2011), dilihat dari proses pengadaan barang murabahah dapat dibagi menjadi 2 diantaranya:

a. Murabahah tanpa pesanan

b. Murabahah Berdasarkan Pesanan (1) mengikat, dimana barang yang sudah dipesan harus dibeli oleh pemesan, (2) tidak mengikat, dimana pemesan tidak wajib memenuhi janjinya.

2. Rukun dan Syarat Murabahah:

a. $B a^{\prime} i=$ penjual (adanya pihak pemilik barang yang akan menjual barang)

b. Musytari = pembeli (pihak yang mengingkan barang dan akan membeli barang tersebut)

c. Mabi' = tersedia barang yang akan diperjual belikan (subyek)

d. Tsaman = harga yang disepakati

e. IjabQabul = pernyataan timbang terima(akad, perjanjian).

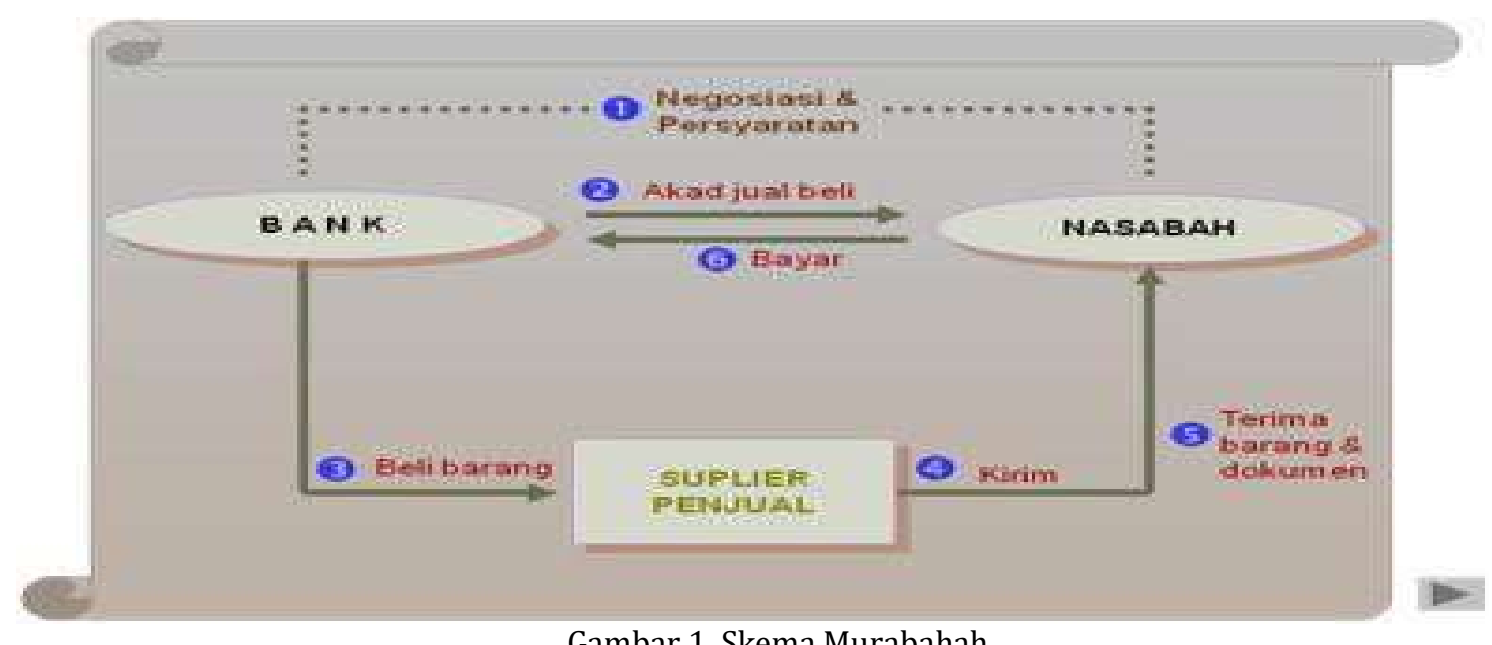

Gambar 1. Skema Murabahah

Syarat-syarat murabahah menurut Syafi'I Antonio( 2005) adalah: (a)Penjual memberitahu biaya barang kepada nasabah, (b)Kontrak pertama harus sah sesuai dengan rukun yang ditetapkan ,(c)Kontrak harus bebas dari riba, (d)Penjual harus menjelaskan kepada pembeli bila terjadi cacat atas barang sesu pembelian, (e)Penjual harus menyampaikan semua hal yang berkaitan dengan pembeli misalnya jika pembelian dilakukan secara hutang.

Menurut PSAK 102 revisi (2013) paragraph 10 dan 12, menyatakan bahwa: Harga yang disepakati dalam murabahah adalah harga jual, sedangkan biaya perolehan harus diberitahukan. Jika penjual mendapatkan diskon sebelum akad murabahah, maka diskon itu merupakan hak pembeli. Diskon atas pembelian barang yang diterima setelah akad murabahah disepakati diperlakukan sesuai dengan kesepakatan dalam akad tersebut. Jika tidak diatur dalam akad, maka diskon tersebut menjadi hak penjual.

Contoh Beberapa produk produk murabahah pada bank syariah diantaranya sebagai berikut: (a) Murabahah untuk Hunian, (b) Murabahah untuk Kendaraan, (c)Pembiayaan Umroh Muamalat, (d) Pembiayaan kepada Anggota Koperasi Karyawan/Guru/PNS Pembiayaan konsumtif yang diperuntukkan bagi beragam jenis pembelian konsumtif kepada karyawan/guru/PNS (selaku end user) melalui koperasi.

\section{Pengertian Struktur Modal}

Weston dan Copeland (2010) memberikan definisi struktur modal sebagai pembiayaan 
permanen yang terdiri dari hutang jangka panjang, saham preferen, dan modal pemegang saham. Nilai buku dari modal pemegang saham terdiri dari saham biasa, modal disetor atau surplus modal dan akumulasi laba ditahan. Bila perusahaan memiliki saham preferen, maka saham tersebut akan ditambahkan pada modal pemegang saham.

Menurut Lawrence, Gitman (2011,), definisi struktur modal adalah sebagai berikut: "Capital Structure is the mix of long term debt and equity maintained by the firm". Struktur modal perusahaan menggambarkan perbandingan antara hutang jangka panjang dan modal sendiri yang digunakan oleh perusahaan.

Secara bahasa (arab) modal atau harta disebut al-amal (mufrad tunggal), atau al-amwal (jamak). Secara harfiah, al-mal (harta) adalah segala sesuatu yang engkau punya. Adapun dalam istilah syar'i, harta diartikan sebagai segala sesuatu yang dimanfaatkan dalam perkara yang legal menurut syara" (hukum islam), seperti bisnis, pinjaman, konsumsi dan hibah (pemberian)

Pengertian modal dalam konsep ekonomi Islam berarti semua harta yang bernilai dalam pandangan syar'i, dimana aktivitas manusia ikut berperan serta dalam usaha produksinya dengan tujuan pengembangan. Istilah modal tidak harus dibatasi pada harta-harta ribawi saja, tetapi ia juga meliputi semua jenis harta yang bernilai yang terakumulasi selama proses aktivitas perusahaan dan pengontrolan perkembangan pada periode-periode lain.

\section{Komponen Struktur Modal}

a. Hutang Jangka Panjang,

Menurut Sundjaja dan Barlian (2006), "hutang jangka panjang merupakan salah satu dari bentuk pembiayaan jangka panjang yang memiliki jatuh tempo lebih dari satu tahun, biasanya 5 - 20 tahun".

b. Modal Sendiri

Menurut Sundjaja at al. (2006, p.324), "modal sendiri/ equity capital adalah dana jangka panjang perusahaan yang disediakan oleh pemilik perusahaan (pemegang saham), yang terdiri dari berbagai jenis saham (saham preferen dan saham biasa) serta laba ditahan". Pendanaan dengan modal sendiri akan menimbulkan opportunity cost... Ada 2 (dua) sumber utama dari modal sendiri yaitu: (1)Modal saham preferen, (2) Modal saham biasa

Sebelumnya dalam PBI tentang BPRS ditentukan persyaratan modal disetor minimum BPRS yang beroperasi di wilayah Jakarta, Depok, Tangerang, Bekasi harus memiliki modal minimum Rp 2 miliar, Rp 1 miliar di ibukota provinsi diluar Jabodetabek dan Rp 500 juta bagi BPRS di luar ibukota provinsi

\section{Imbal Hasil}

Imbal hasil yang akan diberikan atau sebagai acuan adalah disini adalah penggunaan modal sendiri. Menurut Sutrisno (2009:), rentabilitas modal sendiri merupakan kemampuan perusahaan untuk menghasilkan laba dengan modal sendiri.

Pengembalian atas total aktiva merupakan ukuran efisiensi operasi yang relevan. Nilai ini mencerminkan pengembalian perusahaan dari seluruh aktiva (pendanaan) yang diberikan pada perusahaan. Ukuran ini tidak membedakan pengembalian berdasarkan sumber pendanaan .dengan menghilangkan dampak sumber pendanaan aktiva, analisis berpusat pada evaluasi dan peramalan kinerja operasi (wild John, Subramanyam dan Halsey 2010)

Dalam menentukan nilai suatu perusahaan para investor masih menggunakan indikator rasio keuangan untuk melihat tingkat pengembalian yang dapat diberikan oleh perusahaan kepada investor.. Profitability rasio adalah pendapatan atau keberhasilan operasi suatu perusahaanpada periode tertentu. Salah satu alat ukur finansial yang umum digunakan untuk mengukur tingkat pengembalian investasi adalah Return on Assets (ROA).

Return on Assets (ROA) merupakan perbandingan antara laba bersih dengan rata-rata total aktiva yang dimiliki perusahaan (Keiso.D,E, Weygandt.JJ, Warfield.TD, 2008:780). Return on assets (ROA) yang positif menunjukkan bahwa dari total aktiva yang digunakan untuk beroperasi mampu memberikan laba kepada

perusahaan. Sebaliknya apabila return on assets yang negatif menunjukkan bahwa dari total aktiva yang digunakan, perusahaan mengalami kerugian. Sehingga jika suatu perusahaan mempunyai ROA 
yang tinggi yang positif maka perusahaan tersebut berpeluang besar dalam meningkatkan modal sendiri. Tetapi sebaliknya, jika total aktiva yang digunakan perusahaan tidak menghasilkan laba maka akan menghambat modal sendiri.

\section{KERANGKA ANALISIS}

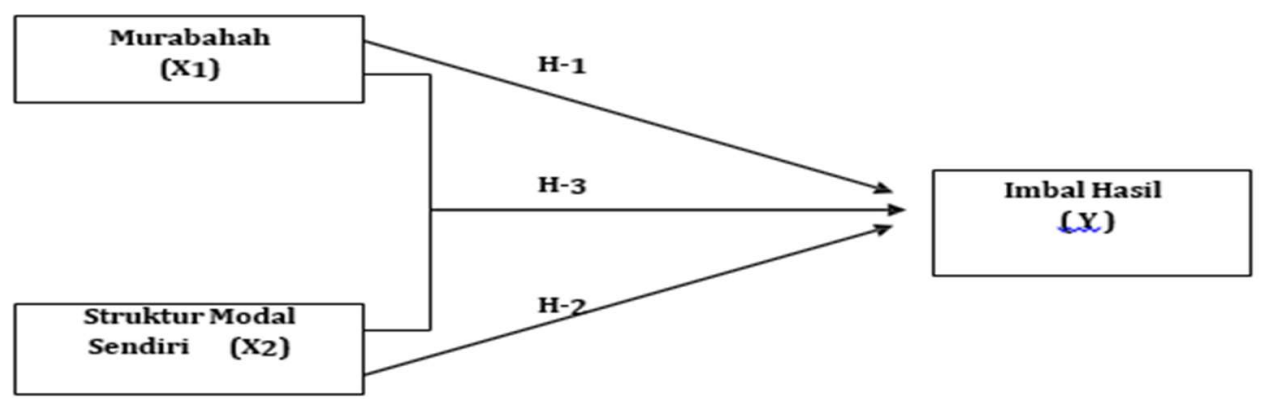

Gambar 2. Kerangka Analisis

\section{HIPOTESIS}

\section{H1: Murabahah berpengaruh terhadap imbal hasil.}

\section{H2: Struktur modal sendiri bepengaruh terhadap imbal hasil}

\section{H3: Murabahah dan Struktur Modal Sendiri secara bersama-sama berpengaruh terhadap imbal hasil.}

\section{Metode Penelitian.}

Penelitian yang dilakukan ini adalah bertujuan untuk mengetahui pengaruh jual beli murabahah dan modal sendiri terhadap imbal hasil yaitu berupa return on asset pada Bank Perkreditan Rakyar Syariah (BPRS) di pulau jawa pada periode quartalan yaitu periode laporan Neraca maret 2011 s/d Desember 2012 yang terpublikasi. Klasifikasi data dengan data pooling dimana terdapat data runtut waktu dan silang tempat, dengan menggunakan data sekunder.

Populasi dalam penelitian ini adalah elemen yang seluruh populasi homogen yaitu keseluruhan individu yang menjadi anggota populasi relative mempunyai sifat yang relatif sama antara yang satu dengan yang lain, yaitu sebagai subyek adalah seluruhnya adalah Bank Perkreditan Rakyat Syariah.

Pemilihan sampel adalah dengan beberapa metode pengambilan sampel yang dipilih mengikuti beberapa hal, dengan ckriteria sebagai berikut:

1. Dengan populasi homogen yaitu dengan subyek yang sama Bank Perkeditan Rakyat Syariah

2. Menentukan daerah yang menjadi sampel yaitu pulau jawa (cluster samping)

3. Menggunakan purposive sampling yaitu dengan pertimbangan khusus diantaranya:

a. Data sekunder yang terpublikasi oleh Bank Indonesia, Publikasi Laporan Keungan Quartalan selama 2 tahun yaitu tahun 2011 s/d tahun 2012 secara lengkap.

b. Dalam Publikasi Laporan Keunan Quartalan ditemukan= (1) Pembiayaan jual beli murabahah, (2) terdapat modal sendiri, (3) Return on Asset (ROA) yang Positif.

Jenis data penelitian adalah dengan menggunakan data sekunder, yaitu diperoleh atau dikumpulkan oleh peneliti dari sumber yang telah ada dimana peneliti sebagai tangan kedua . Data tersebut diperoleh, dikumpulkan dan diambil dari Bank Indonesia yaitu berupa Laporan Keuangan Bank Rakyat Syariah yang terpublikasi artinya data yang dipilih adalah data yang sudah valid. 
Setelah melakukan pemilihan sampel dengan menggunakan criteria yang telah ditepapkan, maka hasil dari pemilihan populasi sampel adalah sebagai berikut:

1. Data BPRS di Indonesia diambil tahun 2012 adalah 155 unit BPRS $=100 \%$

2. Seleski Kriteria kedua dari 155 unit menjadi 99 unit $(63,87 \%)$.

3. Seleksi Kriteria ketiga-a, menjadi 53 Unit BPRS $(34,19 \%)$

4. Seleksi criteria ketiga-b, menjadi 18 Unit BPRS $(11,61 \%)$

Dalam penelitian ini, variabel yang diteliti dibagi menjadi dua kelompok yaitu:

1. Variabel bebas (independent variable)

Variabel yang mempengaruhi atau yang menjadi penyebab terjadinya perubahan atau timbulnya variabel terikat. Dalam penelitian ini variable bebasnya adalah $\mathbf{X 1}=$ Murabahah dan $\mathbf{X} \mathbf{2}=$ Struktur Modal Sendiri

2. Variabel Terikat (dependent variable)

Variabel terikat merupakan variabel yang dipengaruhi atau menjadi akibat,karena adanya variabel bebas. Dalam penelitian ini yang digunakan sebagai variabel terikat $(\mathbf{Y})$ adalah imbal hasil (ROA)

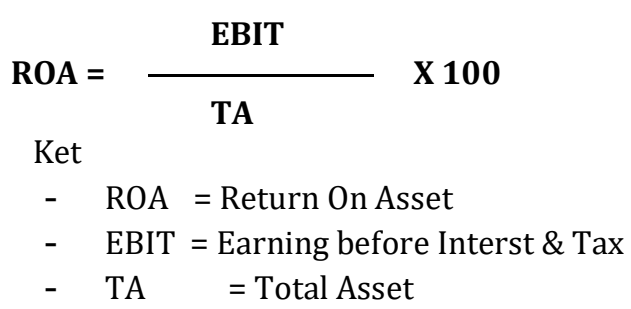

\section{Metode Analisis Data}

Menggunakan Analisis regresi linier berganda dengan persamaan Regresi Linier Berganda adalah sebagai Berikut:

$$
\mathrm{Y}^{\prime \prime}=\mathrm{a}+\mathrm{b} 1 \mathrm{X} 1+\mathrm{b} 2 \mathrm{X} 2+€
$$

Keterangannya:

$\mathrm{Y}^{\prime \prime} \quad$ = Varibel Dependen (imbal Hasil)

a $=$ Konstanta

$\mathrm{b} 1=$ koefisien dari X1

b2 = koefisien dari X2

$\mathrm{X} 1=$ Varibale Independent (Murabahah)

$\mathrm{X} 2$ = Variabel Independent (struktur modal sendiri)

Analisis stastik yang digunakan dalah dengan menggunakan Uji Asumsi Klasik:

1. Uji Normalitas, bertujuan untuk mengetahui apakah distribusi sebuah data mengikuti atau mendekati distribusi normal

2. Uji Multikolinieritas, bertujuan untuk menguji apakah model regresi ditemukan adanya korelasi antar variabel bebas (independent variable).

3. Uji Heteroskedastisitas, bertujuan menguji apakah dalam model regresi terjadi ketidaksamaan veriance dari residual satu pengamatan ke pengamatan yang lain..

4. Uji Autokorelasi bertujuan menguji apakah model regresi linier ada korelasi antara kesalahan pengganggu pada periode $\mathrm{t}$ dengan kesalahan pengganggu pada periode sebelumnya $(\mathrm{t}-1$

Pengujian Hipotesis menggunakan Uji Linier Berganda merupakan salah satu pengujian hipotesis untuk mengetahui pengaruh antara variabel bebas (independen) terhadap variabel tetapnya (dependen). 


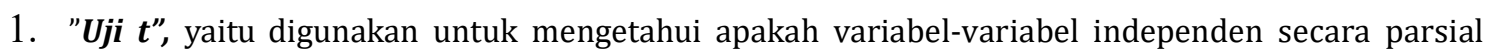
berpengaruh nyata atau tidak terhadap variabel dependen, untuk uji t" ini yang diuji adalah variable independen yaitu $\mathrm{H} 1$ dan $\mathrm{H} 2$

2. “Uji F”, yaitu digunakan untuk mengetahui apakah variabel-variabel independen secara simultan berpengaruh signifikan terhadap variabel dependen Untuk pengujian „Uji F” ini yang diuji adalah variabel $\mathrm{H} 3$.

3. Koefisien determinasi $\left(\boldsymbol{R}^{2}\right)$ yaitu digunakan untuk mengetahui seberapa besar hubungan dari beberapa variabel dalam pengertian yang lebih jelas. Koefisien determinasi akan menjelaskan seberapa besar perubahan atau variasi suatu variabel bisa dijelaskan oleh perubahan atau variasi pada variabel yang lain

\section{HASIL DAN PEMBAHASAN Hasil uji Statistik}

Berdasarkan hasil uji normalitas diketahui bahwa data di sekitar garis diagonal dan mengikuti arah garis diagonalnya, maka model regresi memenuhi asumsi normalitas memiliki signifikansi sebesar 0,385> 0.05, maka Ho diterima.

Berdasarkan hasil multikolinearitas diketahui bahwa seluruh variabel independen pada model regresi mempunyai nilai VIF kurang dari 10. Sehingga H0 diterima, yang berarti tidak ada hubungan yang sangat kuat antara variabel independen

Berdasrkan hasil uji Autokorelasi menunjukkan bahwa bahwa model yang diteliti mempunyai jumlah observasi sebesar 144, dengan jumlah variabel bebas sebesar 2. Hasil uji durbinwatson statistik yang diperoleh dari pengujian adalah sebesar 1,833, berada di area $d U<$ dw $<4$ $d U$, atau berada diarea tidak ada autokorelasi.

Berdasrkan hasil uji heteroskedastisitas diketahui bahwa tidak ada pola yang jelas, serta titik - titik menyebar di atas dan di bawah angka 0 pada sumbu Y, peneliti menyimpulkan bahwa tidak terjadi heteroskedastisitas pada model regresi yang digunakan.

Berikut persamaan regresi yang terbentuk :

Imbal Hasil = 1,826-0,016 Murabahah + 0,000000212 Struktur Modal Sendiri+ $\varepsilon$

Ha1 Murabahah berpengaruh terhadap Imbal Hasil.

bahwa tingkat Murabahah mempunyai koefisien regresi yang negatif sebesar

-0,016 terhadap Imbal Hasil. Hal ini dapat diartikan jika tingkat Murabahah meningkat sebesar satu satuan maka Imbal Hasil akan turun sebesar 0,016 satuan, yang berarti tingkat Murabahah berpengaruh terhadap Imbal Hasil.

Ha2: Struktur modal sendiri berpengaruh terhadap Imbal Hasil.

bahwa struktur modal sendiri mempunyai koefisien regresi yang positif sebesar 0,000000212 terhadap Imbal Hasil. Hal ini dapat diartikan jika struktur modal sendiri meningkat sebesar satu satuan maka Imbal Hasil akan meningkat sebesar 0,000000212 satuan, yang berarti struktur modal sendiri berpengaruh terhadap Imbal Hasil.

Ha3: Murabahah dan struktur Modal Sendiri Secara bersama-sama berpengaruh terhadap imbal hasil.

bahwa F-hitung sebesar 12,118 dengan nilai signifikansi sebesar $0,000<\alpha 0,05$. Maka $\mathrm{Ha}_{\mathrm{a}}$ diterima yang berarti Tingkat Murabahah dan struktur Modal Sendiri Secara bersama-sama berpengaruh terhadap imbal hasil.

\section{Analisis Penelitian}

Hasil dari uji statistik mengenai pengaruh variabel independent (bebas) terhadap variabel dependent (terikat) adalah sebagai berikut: a:

1. Hasil uji normalitas menunjukan memiliki signifikasi $0,385>0,05$, maka Ho adalah normal, artinya variabel X1, X2 dan vaiabel $\mathbf{Y}$ mempunyai distribusi normal.

2. Hasil uji multikolineritas menunjukan seluruh variabel independent mempunyai nilai $\mathrm{VIF}<10$, artinya Ho diterima, artinya Variabel $\mathbf{X 1}$ dan Variabel X2 tidak ada multikolineritas atau 
hubungan yang kuat

3. Hasil uji autokorelasi menunjukan jumlah observasi dari 144 sampel menunjukan dl 1,706, du 1,706. Uji dubinwatson statistic menunjukan 1,833, yaitu berada di area tengah $\mathrm{du}<\mathrm{dw}<4-\mathrm{du}$, berada diarea tidak atukorelasi artinya tidak ada auotokorelasi pada model regresi yang digunakan

4. Hasil uji heteroskedatisitas menunjukan gambar tidak ada pola yang jelas, serta titik menyebar diatas dan dibawah anagka 0 pada sumbu Y, maka dapat disimpulkan bahwa tidak terjadi heteroskedastisitas atau ketidaksamaan varian dan residual satu pengamatan ke pengamatan yg lain

Hasil analisa regresi linier pada penelitian ini adalah sebagai berikut:

1. Pengujian R2 dan adjusted R2 menunjukan bahwa nila adjusted R2 adalah 0,135 artinya seluruh variabel X1 dan variabel X2 mampu menjelaskan variabel Y yaitu sebesar 13,5\% sedangkan sisanya dapat dijelaskan oleh faktor lainnya yg tidak diikutsertakan dalam pengujian.

2. Hasil Uji t" menunjukan bahwa konstanta nilai sebsear 1,826, nilai signifikasi dari hasil uji t ini sebsar 0,000<0,05, maka konstanta berpengaruh signifikasi terhadap imbal hasil.

\section{a. Ha1 : Murabah berpengaruh terhadap imbal hasil}

Bahwa variabel murabahah (X1) berpengaruh terhadap Imbal Hasil (Y), hasil pengolahan variable Murabahah mempunyai regresi -0,016 (negative), bahwa jika murabahah meningkat sebesar satu satuan maka imbal hasil akan turun sebesar 0,016 satuan.

Hasil penelitian ini sejalan dengan penelitian Aulia, R dan Rohmanica,R., (2012) bahwa bahwa dari hasil uji koefisien bahwa pembiayaan jual beli (murabahah) berpengaruh positif terhadap profitabilitas artinya pengaruh jual beli murabahah sangat menentukan profitabilitas (ROA)

Berpengaruh negatifnya tingkat murabahah terhadap imbal hasil menunjukkan tingkat murabahah yang dihasilkan belum dapat secara langsung meningkatkan atau memperoleh imbal hasil yang baik, hal memang diperlukan adanya pendukung bisa saja dalam bentuk tambahan modal dan atau dengan jenis pembiayaan mudharabah.

b. Ha2 : Struktur modal sendiri berpengaruh terhadap imbal hasil Bahwa Variabel Struktur modal sendiri (X2) berpengaruh terhadap variabel imbal hasil (Y) Hasil pengolahan Sendiri mempunyai koefisien beta 0,0000000212 (positif), bahwa jika struktur modal sendiri meningkat sebesar satu satuan maka imbal hasil akan meningkat sebesar 0,0000000212 satuan.

Hasil penelitian ini sejalan dengan penelitian sebelumnya oleh Rosyadah, F., Suhadak, dan Darminto, (2012) bahwa struktur modal berpengaruh positif terhadap profitabilitas Return on Asset (ROA) dengan hasil uji posistif. .Hasil penelitian ini sejalan dengan penelitian Rahim dan Irpa (2008) yang menemukan bahwa struktur modal dapat berpengaruh signifikan terhadap profitabilitas atau imbal hasil yang diukur dengan ROA.

Berpangaruhnya positif antara struktur modal sendiri terhadap imbal hasil adalah memang sangat diperlukan, artinya jika semakin tinggi modal sendiri maka secara otomamatis akan menambah imbal hasil namun harus didukung oleh transaksasi produk pembiyaan yang lain.

3. Hasil uji statistik $\boldsymbol{F}$ (Anova), menunjukan bahwa seluruh variabel bebas (X1 dan X2) secara bersama-sama dimasukan dalam satu model regresi $\mathbf{F}$ dengan hitungan 12,118 dengan nilai signifikasi 0,000<a0,05, maka Ha diterima berarti murabahah (X1) dan struktur modal sendiri (X2) berpengaruh positif terhadap imbal hasil (Y)

Ha3 : Murabahah dan struktur modal sendiri secara bersama berpengaruh terhadap imbal hasil

Hasil penelitian ini sejalan dengan penelitian Rah kedua penelitian yang dilakukan oleh Rahmanita R (2012) tentang pengaruh murabahah dan Suhadak, dan Darminto, (2012) tentang pengaruh struktur modal, kedua penelitian tersebut berpengaruh terhadap imbal hasil (Retunr on Asset). 


\section{KESIMPULAN}

1. Menunjukkan bahwa Murabahah berpengaruh negative terhadap Imbal Hasil.

2. Menunjukkan bahwa Struktur Modal Sendiri berpengaruh positif signifikan terhadap Imbal Hasil,

3. Menunjukkan bahwa Tingkat Murabahah dan struktur Modal Sendiri Secara bersama-sama berpengaruh positif terhadap imbal hasil.

\section{SARAN}

1. Agar peneliti selanjutnya dapat mencari sample lebih banyak lagi sehingga data akan lebih akurat

2. Agar penelti yang akan datang bisa menambah variable dan atau merubah variable sehingga bisa menambah wacana baru dan lebih baik.

3. Agar peneliti yang akan datang bisa menambah cakupan analisis dengan harapan akan menambah banyak masukan dan pendapat.

\section{DAFTAR PUSTAKA}

Aulia, R dan Rohmanica,R., (2012) Pengaruh Pembiayaan Jual Beli, Pembiayaan Bagi Hasil, dan Rasio Non Performing Financing terhadap Profitabilitas Bank Umum Syariah di Indonesia, Jurnal, Surabaya, Univ Brawijaya

Brealey, R.A., Stewart C.M., dan Alan J.M. (2009). Dasar-dasar Manajemen Keuangan Perusahaan, terjemahan buku Fundamentals of Corporate Finance., Erlangga, Edisi Kelima. Jakarta.

Barclay,M.J., \& Smith,C.W., (2005), The Capital Structure Puzzle: The Evidence Revisited. Journal of Applied Corporate Finance Vol.17, No. 1, 8-17

Harahap.SS, (2007), Krisis Akuntansi Kapitalis dan peluang akuntansi Syariah, Jakarta, Pustaka Quantum Indonesia,A.I., (2008), Kerangka Dasar Penyusunan dan Penyajian Laporan Keuangan Syariah-101, Jakarta Penerbit Salemba,

Indonesia,A.I., (2013), Pernyataan Standar Akuntansi Keuangan no-102, tentang Akuntansi murabahah, Jakarta, Salemba Empa

James C. Van Horne dan John M. Wachowicz. 2012. Fundamental of Financial Management (Prinsip Manjemen Keungan) Buku satu edisi 13. Salemba Empat Jakarta

James,C., Horne,V., \& Jhon,M. wachowicz, JR. (2005), Fundamental of Financial Managemen, terjemahan Prinsip-prinsip Manajemen Keuangan (Edisi Kedua belas, Jakarta,Salemba Empat.

Keiso.D,E, Weygandt.JJ, Warfield.TD, (2008) Intermediate Accounting, Terjemahan Copyright ,edisi 8, Erlangga, Jakarta,

Keuangan,O.J, (2008), Surat Edaran Bank Indonesia Nomor 10/31/DPbS, http://www.ojk.go.id/suratedaran-bank-indonesia-nomor-10-31-dpbs

Lawrence J. Gitman, Chad J. Zutter (2011), Principles of Managerial Finance 13th Edition, Prentice Hall finance series, 13th edition, London

Oktriani,Y., (2012), Pengaruh Pembiayaan Musyarakah, Mudharabah, dan Murabahah Terhadap Profitabilitas (Studi Kasus PT. Bank Muamalat Indonesia, Tbk.), Journal Accounting Vol.1 No.1, Tasikmalaya, Universitas Siliwangi

Ponco.B (2008), Analisis Pengaruh CAR, NPL,BOPO,NIM dan LDR terhadap ROA, Studi Kasus Pada Perusahaan Perbankan yang Terdaftar di Bursa Efek Indonesia Periode 2004-2007), Tesis, Semarang ,Undip

Riyanto, B., ( 2011), Dasar dasar Pembelanjaan Perusahaan, Yogyakarta, BPFE. Edisi ke empat (4)

Ridwan, S. Sundjaya \& Inge, Barlin. (2006). Manajemen Keuangan. Jilid 2. Edisi Keempat. Literata Lintas Media. Bandung

Rosyadah, F., Suhadak, dan Darminto, (2012), Pengaruh Struktur Modal Terhadap Profitabilitas (studi pada perusahaan real estate and property di BEJ 2009-20011, Jurnal, Surabaya, Univ Brawijaya

RosadyRuslan, (2010) Metode Penelitian Public Relations dan Komunikasi,: Rajawali Pers, Jakarta Sundjaja,R., Barlian.I., (2003), Manajemen Keuangan 2 Edisi Keempat, Yogyakarta, BPFE

Sutrisno. (2009). Manajemen Keuangan, Teori, Konsep dan Aplikasi. ekonesia, Bandung, 
Sugiyono. (2009). Metode Penelitian Pendidikan, Pendekatan Kuantitatif, Kualitatif, dan R \& D, Alfabeta. Bandung

Sukmadinata.N,S (2011). Metode Penelitian Pendidikan. Bandung: PT Remaja Rosdakarya.

Syafi"i,M.A., (2005), Bank Syariah Dari Teori ke Praktek, Jakarta, Gema Insani Press.),

Wild, John J., Subramanyam.K.R., dan Halsey, Robert, (2010). Analisis Laporan Keuangan, Alih Bahasa; Yanivi S. Bachtiar dan S. Nurwahyu Harahap, Buku 2, Edisi kesepuluh, ,Salemba Empat, Jakarta.

Weston.J.F dan Copeland.T.E.,(2010), Dasar - Dasar Manajemen Keuangan, Erlangga., Perusahaan, Edisi III : Jakarta .

Wiroso, ( 2011), Produk Perbankan Syariah, Jakarta, LPFE-USAKTI

Zubaidah.S, (2008), Analisis Struktur Pembiayaan dan Pengaruhnya Terhadap Kinerja Keuangan Study Pada Perbankan Syariah, Tesis, Malang, FE UMM 